\title{
Fusionando la realidad aumentada en la educación bilingüe y ESL: Percepciones de futuros maestros
}

\author{
Infusing Augmented Reality in Bilingual and ESL Education: \\ Perceptions from Pre-service teachers
}

\section{(iD) Jorge F. Figueroa Flores}

Department of Teacher Education, Texas Woman's University, United States of America

jfigueroa2@twu.edu

\section{(iD) Lisa Huffman}

Department of Human Development, Family Studies and Counseling, Texas Woman's University, United States of America

Ihuffman@twu.edu

\section{(D) Emarely Rosa Dávila}

Department of Social Work, Texas Woman's University, United States of America

erosadavila@twu.edu

\section{RESUMEN}

En los últimos años, los programas de Formación Docente han aumentado el interés por capacitar a sus futuros maestros en la integración de las tecnologías inmersivas. Esto había llevado a un mayor auge y exploración de las posibilidades de enseñanza de estas tecnologías, especialmente con la realidad aumentada y su integración al aula bilingüe y de inglés como segundo idioma (ESL). El siguiente artículo presenta un estudio reciente que se realizó en la Texas Woman's University con $n=27$ futuros maestros bilingües y de ESL. Sirvió como piloto y buscó determinar las percepciones de los futuros maestros en sobre las fortalezas y limitaciones en el uso de la realidad aumentada (RA) para el aula bilingüe y de ESL. También buscó proporcionar una comprensión de posibles aplicaciones móviles, implicaciones educativas y actividades para el aula. El estudio utilizó un método cualitativo siguiendo un diseño exploratorio e integró un análisis de contenido. Los resultados indicaron que los participantes ven la RA como una fortaleza para mantener a los estudiantes comprometidos y motivados. Por otro lado, el acceso a la tecnología fue percibido como una limitación. La integración de aplicaciones de RA como Quiver y HP Reveal junto con la integración de la Enseñanza Culturalmente Relevante (Gay, 2013) apoyó en la creación de actividades (por ejemplo, muros de RA y demostraciones de clase) que fueron percibidas por los candidatos a maestros como posibilidades para apoyar el aprendizaje en el aula bilingüe y de ESL. El estudio también señaló la necesidad de más investigación sobre el tema.

PALABRAS CLAVE realidad aumentada, formación docente, educación bilingüe, ESL, tecnologías inmersivas. 


\section{ABSTRACT}

In recent years there has been an increased interest by Teacher Education programs to train its pre-service teachers with immersive technologies. This had led to a greater boom and exploration of teaching possibilities of these technologies, especially with augmented reality and its integration to the bilingual and ESL classroom. The following article presents a recent study that was conducted at Texas Woman's University with $n=27$ bilingual and ESL pre-service teachers. It served as a pilot and sought to determine pre-service teachers' perceptions on the strengths and limitations in the use of augmented reality for the bilingual and ESL classroom. It also sought to provide an understanding of potential mobile applications, educational implications and activities for the classroom. The study used a qualitative method following an exploratory design and integrated a content analysis. The findings indicated that the participants view AR as a strength to keep students engaged and motivated. On the other hand, access to AR technology was perceived as a limitation. The integration of AR applications such as Quiver and HP Reveal along with the integration of Culturally Relevant Teaching (Gay, 2013) supported the creation of activities (e.g., AR walls and class demonstrations) that were perceived by pre-service teacher candidates as possibilities to support learning in the bilingual and ESL classroom. The study also pointed out the need for more research on the topic.

KEYWORDS augmented reality, teacher education, bilingual education, ESL, immersive technologies.

\section{INTRODUCTION}

Increased use of technology in educational settings has created the need to reexamine the teaching and learning process. We've moved from a traditional classroom setting to one focusing on innovation, where Information and Communications Technologies (ICTs) play an important role (Marín-Díaz et al., 2015). Innovations seen in $\mathrm{K}-12$ classrooms have encouraged teacher education programs to include training with some of the latest technologies available while moving away from the Web 2.0. One of these technologies is Augmented Reality (AR) which is a simulated, but enhanced, reality that combines both computer-generated virtual and real-world data to allow users to complete real-time interactions with computer-generated graphics, imagery, and objects, in a smooth way and with an illusion of these layers of information coexisting in the same space (Kang, \& Yang, 2020). When used properly, this technology gives the student the opportunity to layer data and images over material in actual spaces. In order for the digital layer to come to live, it will use a trigger or target. This is similar to the concept of the QR code (Donally, 2018). In addition, AR energizes the learning processes by promoting the development of digital competencies (George, 2020).

In the field of bilingual and ESL education, technology has transformed dramatically the teaching and learning process. Throughout the years this field has become more technology oriented and transitioned effectively from Computer Assisted Language Learning (CALL) to Web 2.0 (Figueroa-Flores, 2015). Today, the use of technology in the bilingual and ESL classroom has become the biggest scaffold for second language acquisition and a connection between different generations (Figueroa-Flores, 2016). In addition, it has been demonstrated that technology lowers the affective filter (Krashen, 1982). Training bilingual and ESL preservice teachers on how to integrate AR in the classroom will give them a leverage in strengthening skills of students when they arrive at their classroom. In addition, AR is a non-linguistic technology that will permit the learner to generate a mental image and elaborate knowledge. This will give an additional leverage to the 
bilingual and ESL teachers when they link AR in order to strengthen the vocabulary skills of their emerging bilinguals and it will give them the opportunity to integrate Translanguaging (García, \& Kleifgen, 2018).

Decidedly, there is very limited research on the use of AR in teacher education, and the opportunities it could provide to the bilingual and ESL classroom, but the research that has been done has found effective use and best practices for the teaching and learning process (Bonner, \& Reinders, 2018). This is why more than ever it's relevant to do research in this field, especially for bilingual and ESL students. The following article showcases a pilot study that sought to determine the perceptions of bilingual and ESL pre-service teachers on the strengths and limitations in the use of AR for the classroom. It also sought to provide an understanding of the potential mobile applications that could be integrated, along with educational implications and activities for the bilingual and ESL classroom.

\section{METHODOLOGY}

This study served as a pilot and was conducted during Spring 2019 with $n=27$ bilingual and ESL pre-serving teachers from Texas Woman's University (TWU), a higher education institution located in the city of Denton, TX. This institution is a hispanic serving institution (HSI) and is the largest university primarily for women in the United States. The study sought to determine the perception of bilingual and ESL pre-service teachers with the strengths and limitations of AR for the classroom. In addition to providing an understanding based on experiences with AR mobile applications, educational implications, and activities. The study questions were:

Q1: What are the strengths of integrating augmented reality in the bilingual and ESL classroom?

Q2: What are the limitations of integrating augmented reality in the bilingual and ESL Classroom?

Q3: Which augmented reality applications would you integrate to your bilingual or ESL classroom?

Q4: What educational implications would you integrate to your bilingual or ESL classroom?

Q5: What activities with augmented reality would you integrate to your bilingual or ESL classroom?

From the $n=27$ participating bilingual and ESL pre-service teachers, 96\% identified themselves as female and $13 \%$ as male. In addition, $100 \%$ of the pre-service teachers were undergraduate students enrolled in three different undergraduate course sections of EDBE 4453-Theories of Second Language Acquisition for ESL and Bilingual Teachers. Regarding their academic year, 15\% indicated they were in their sophomore year, 64\% indicated that they were in their junior year and 21\% indicated that they were in their senior year. A total of 55\% of the participants were pursuing an ESL certification, 35\% a bilingual education certification, and $10 \%$ a triple certification in elementary education, ESL, and special education. None of the participants had academic experience with the use of AR.

All pre-service teachers received six hours of specialized classroom training in the educational use of AR. In addition, supplemental resources were provided online to all the students throughout the course. The classroom training and online supplemental resources included: classroom presentations with examples on AR, online videos and tutorials about AR, potential activities for the bilingual and ESL classroom with AR, alignment with state standards, and exploration of AR applications. For the classroom training, students were provided with iPads. In addition, some used their own devices (iOS and Android, smartphones, iPads or Android tablets). The AR applications presented in Table 1 were integrated as part of the classroom training and instruction. 
TABLE 1. AR Applications

\begin{tabular}{ll}
\hline & App name \\
\hline App 1 & Quiver \\
\hline App 2 & JigSpace \\
\hline App 3 & HP Reveal \\
\hline App 4 & Metaverse \\
\hline App 5 & Augment \\
\hline App 6 & StoryFab \\
\hline App 7 & Google Translate \\
\hline App 8 & Animals +4D \\
\hline App 9 & PhotoMath \\
\hline Total apps & $\mathbf{9}$ \\
\hline
\end{tabular}

construct theory from data, systematically obtained and analysed using comparative analysis. The instrument for data collection included guided reflections using the study questions. The categories of the guided reflections were classified in strengths of integrating AR, limitations of integrating AR, applications, educational implications, and activities of AR in the classroom. Upon data collection, answers were coded and Content Analysis was implemented. According to Krippendorf (2004), Content Analysis is the systematic reading of a body of texts, images, and symbolic matter, not necessarily from an author's or user's perspective. For data collection, the technique used was guided reflections. This approach was used to analyze and interpret the reflections. After the six hours of classroom training were met, the participants were given a worksheet with the study questions on which they reflected. The total number of references were gathered by category and NVivo Plus 12 for Windows software was used to provide support to the analysis.

\section{RESULTS}

Table 2 below shows the categories, number of participants, coded number of references and percentages of total coded references for the study.

TABLE 2. Categories

\begin{tabular}{lccc}
\hline & $\begin{array}{c}\text { Num.of } \\
\text { Participants }\end{array}$ & $\begin{array}{c}\text { Coded } \\
\text { References }\end{array}$ & $\begin{array}{c}\text { Percen- } \\
\text { tage }\end{array}$ \\
\hline $\begin{array}{l}\text { Strenghts of } \\
\text { integrating AR }\end{array}$ & 27 & 203 & $45 \%$ \\
\hline $\begin{array}{l}\text { Limitations of } \\
\text { integrating AR }\end{array}$ & 27 & 71 & $16 \%$ \\
\hline Applications & 27 & 58 & $13 \%$ \\
\hline $\begin{array}{l}\text { Educational } \\
\text { implications }\end{array}$ & 27 & 53 & $12 \%$ \\
\hline Activities & 27 & 67 & $14 \%$ \\
\hline Total & $\mathbf{2 7}$ & $\mathbf{4 5 1}$ & $\mathbf{1 0 0 \%}$ \\
\hline
\end{tabular}

The categories included: strengths, limitations, applications, educational implications, and activities.

In the category titled strengths of integrating AR a total of 203 entries were coded. The participants highlighted with $46 \%$ (93) as the top strength that AR in the bilingual or ESL classroom enhances classroom engagement. In addition, 28\% (56) of the pre-service teachers participating in the study mentioned that it motivates students to learn. Other strengths highlighted as part of this category included: fun and new ways to learn with $11 \%$ (23\%), promotes a visual learning experience with $9 \%$ (17), 
lowers the affective filter with 3\% (7), and inclusive technology with 3\% (7). Below are examples of some of the pre-service teachers reflections with this category:

Participant 6 - "Using augmented reality in my bilingual classroom will make students feel more engaged and motivated to learn. This is one of the many strengths I see. Students will have the opportunity to participate in a relaxed atmosphere that will lower their affective filter. I believe with AR all my students will be able to participante. This is one of the most inclusive technologies I've seen."

Participant 13 - "The experience with augmented reality was surreal. This technology enhances classroom engagement, so beneficial for emerging bilinguals. Most of all it's fun and inclusive. Everyone in my classroom can get involved and learn".

Participant 23 - "One benefit that I see for augmented reality is that I can help students learn a new subject in a new and fun way".

As it was previously mentioned, another category was limitations of integrating AR. A total of 71 entries were coded in this category. Pre-service teachers participating in the study highlighted with 46\% (33) accessibility to mobile devices as the primary limitation followed by access to the Internet with $25 \%$ (18). Other highlighted mentions by the participants included: students not able to follow instructions with 14\% (10), technology setup with $4 \%$ (3), teachers not familiarized with the technology with 3\% (2). Examples of the pre-service teachers reflections can be found below:

Participant 1 - "It's hard to see limitations with this type of technology, but definitely not everyone has a smartphone or mobile device. Also, there are places in the state where the internet never arrives. This type of technology needs the support of the internet and what will happen if we don't have it".

Participant 8 - "A limitation that I see is regarding to teachers not knowing how to set up this technology for the classroom and the familiarization. There are teachers that don't know how to access the internet and this technology could frustrate them.

Participant 17 - "Limitations for me include no access to mobile and other technology devices. Not all students have a device, and if the school doesn't provide any, students can be left behind.

The third category of this study was applications and a total of 58 items were coded. The primary application highlighted by the participants was HP Reveal with 50\% (28), followed by Quiver with 21\% (12) and JigSpace with 17\% (10). Other mentions included StoryFab with 9\% (8), and Augment with 3\% (2). Examples of the pre-service teachers reflections with this category can be found below:

Participant 13 - "From all the applications I experienced, HP Reveal was the best. HP Reveal will give me the opportunity to teach a subject. I can't wait to use this in my ESL classroom. It will be fun to create projects with it too".

Participant 19 - "I loved HP Reveal and I also enjoyed working and creating a video with JigSpace. My bilingual students will benefit from its existing content. Also, it will be of great support for the teacher. It's easy to work with. I enjoyed the different projects". 
Participant 23 - "I will combine HP Reveal, Quiver, and JigSpace. HP Reveal will stimulate the mind of my students. Overall, The most I liked was Quiver. I plan to integrate it with my ESL students. I can adjust it to any age and the visual scaffolding is great".

Next in the categories, with a total of 53 items coded was educational implications. The participants highlighted vocabulary support as the top educational implication with $36 \%$ (19) followed by culturally relevant teaching with 23\% (12), and project based learning with 19\% (10). Other mentions included: collaborative work with 13\% (7), homework support with $9 \%$ (5), and flipped classroom with $8 \%$ (4). Some examples of the pre-service teachers reflections with this subcategory can be found below:

Participant 5 - "I understand that vocabulary support with AR is an educational implication for the bilingual and ESL classroom. The technology works as a scaffor and will help non-native speakers of English with technical vocabulary".

Participant 13 - "After checking the possibilities of AR for the bilingual and ESL classroom, I think the educational implications of vocabulary support, culturally relevant teaching, and homework support should be considered. I see the power it has for enabling conversations with families whose English is their second language and most of all to strengthen cultural connections through culturally relevant teaching and project that enhance it”.

The last of the categories was activities. In this category a total of 67 items were coded with the activity of AR walls leading with $42 \%$ (28). I was followed by content demonstrations with $24 \%$ (16), and cognates exercises with $15 \%(10)$. Finally, the participant mentioned science fair with $12 \%(8)$, and scavenger hunts with $7 \%$ (5). Following are examples of the entries by the participants in this category:

Participant 11 - "With AR I'm able to do AR video walls. My students will be able to work with projects and place the trigger image or paper on the wall. Then using one of the apps available, like HP Reveal the trigger image will come to life. This can also serve to showcase students' work, especially during parent and teacher conferences. Another activity will be creating cognates exercises. This will be great for my bilingual class! Spanish and English has similar words and my students will benefit from this".

Participant 27 - "After receiving training with AR, I saw many possibilities for my future ESL classroom. One of them will be for me to conduct class demonstrations. I envision me teaching about a specific subject as part of a class and students seeing the concept come to life through AR. I also plan to record myself in video and share the class demonstrations on the class website. Another activity that I will use with my students will be during the scientific fair. Students will be able to integrate AR technology to their projects".

\section{DISCUSSION}

The top perception regarding strengths of AR highlighted by participants was that AR enhances student engagement. This finding aligns with the perception that integrating technology in the classroom provides 
means to enhance student learning and engagement (Folkestad, \& O'Shea, 2011; Lee, 2012; Saidin et al., 2015). Another strength perceived and highlighted by participants was motivation. This is aligned with the work of De la Horra Villacé (2017), who mentioned that motivation is one of the pillars by which learning methodologies are created. Therefore, AR provides the means to achieve this end. For many years' bilingual and ESL teachers have worked to enhance the personality factors of their emerging bilinguals as a way to increase language learning (Figueroa-Flores, 2016). Integrating AR could motivate emerging bilinguals based on the opportunity it gives of discovering resources (Kerawella et al, 2006; Khan et al., 2019). Motivation can also lower the affective filter (Krashen, 1982) of the emerging bilinguals giving them the opportunity to learn the language more rapidly and less $h$ anxiety. Lowering the affective filter was another strength highlighted by the participants along with fun and new ways to learn, promotes visual learning and inclusive technology.

The participants of the study perceived accessibility to the mobile devices and to the internet as a possible obstacle or limitation to integration of this technology to their classrooms. According to McFarland et al. (2017), AR applications are readily available and the needed tools are in the hands of young people. But for the bilingual and ESL pre-service teachers participating in this study it is evident that not all schools and/ or school districts have mobile devices or the economical flexibility to acquire such devices or to increase bandwidth of the internet. At the same time, while studies have reported that over $80 \%$ of $\mathrm{K}-12$ and over 95\% of university students either own or have access to a smartphone or tablet (Dahlstrom, \& Bichsel, 2014), not all students are allowed to bring a smartphone or tablet into the classroom. Beyond hardware, access to the internet is not universally available and in some areas the majority of households can not afford to pay for access. These two potential limitations foster the digital divide (Marín-Díaz, 2017).

The other limitations highlighted by the students included: students not being able to follow instructions, difficulty with technology setup, and teachers not being familiar with AR technology. Additionally, in the classrooms emerging bilinguals will have different levels of proficiency with their native language and/ or the target language. As such, the teacher will have to spend more time in preparing and differentiating materials, while also dealing with the personality factors of the students to keep students motivated. As with technology setup and teachers not familiarized with technology, the school and/or the school districts will need to devote training for the teachers in order to use this technology effectively in the classroom, but most of all make the teachers feel confident about using it by familiarizing with it and learning to set it up. Training is necessary for teachers. Depend solely in an individual auto formation could create problems in the long run. Not all teachers are digital natives and not all teachers are technology driven.

At the moment this study was conducted, the participants highlighted HP Reveal as the main application they would integrate to their classrooms. Regretfully, this application is no longer available as Hewlett Packard discontinued it. This application, formerly known as Aurasma, was available for iOS and Android and permitted in-service teachers, pre-service teachers, and students to create and view AR experiences. This application gave the opportunity to the participants of the study of creating content without coding. In addition, the participants mentioned Quiver. This free version of the brand permitted them to closely experience AR through coloring worksheets. Its ease of use gives the teacher the opportunity to periodically integrate it in different age groups and grades, align it with the content delivered and the state standards, and promote culturally relevant teaching. All of this will benefit greatly the emerging bilinguals. The participants in the study experienced a volcano erupt, move around different birds, and see in 3D movement a firetruck. Quiver offers a variety of paid resources like Quiver Edu. Another application mentioned by the participants 
was JigSpace. This application comes with content that could be integrated to the classroom. The participants were able to record themselves and observe their explanations of the content. The application comes with specific descriptions but teachers and emerging bilinguals could create content by integrating it sister application JigWorkshop and then uploaded to the JigSpace app. The only limitation perceived by the participants of the study with JigSpace is that it only works with iOS. Finally, StoryFab and Augment, which were the last two highlighted by the participants, provided an immersive AR experience more aligned to strengthening the literacy skills of the emerging bilinguals. The participants in the study were able to create simulated worlds, scenes, and stories.

The participants of this study highlighted vocabulary support as the top educational implication for the bilingual and ESL classroom with AR. This technology permits the teachers to present new vocabulary and technical vocabulary in an engaging and 3D format, instead of an abstract way. According to Goodwin-Jones (2016), there are a number of projects that use AR to help teach vocabulary. Another educational implication highlighted included Culturally Relevant Teaching. Combining AR and CRT has many possibilities, as seen in the work of Petrucco and Agostini (2016). One example could be by integrating and solving relevant mathematical word problems referencing diverse cultures and using an AR app to support the math process. This process becomes culturally relevant when the emerging bilinguals provide alternatives to work with the situation presented and are trained in the use of abstract questions. Lastly, other educational implications mentioned included collaborative work, homework support, and the flipped classroom.

As part of this study, the participants highlighted AR walls, and content demonstrations as their top two activities to integrate to the bilingual and ESL classroom with AR. Using AR walls in the classroom provides teachers and students the ability to showcase their projects to everyone who visits the classroom. This involves using markers, images that are hard-coded into the application, which trigger some kind of action (Godwin-Jones, 2016). In addition, it's a great way for students to share knowledge. In the bilingual and ESL classroom the teacher could assign a project to a group of emerging bilinguals. The different parts of the project could be showcased using an AR wall. In this AR wall the trigger images or QR codes will be placed in one of the classroom walls and everyone will be able to see the trigger images come to life. This type of activity is very engaging and can be set for emerging bilinguals to practice their Translanguaging skills. In addition, content demonstrations give the teachers and the emerging bilinguals the opportunity to demonstrate a concept live in AR. With this strategy classroom the classroom becomes a huge lab for creation and elaboration of content. All of this enabled and shared through one of the many available AR applications. The other activities mentioned included cognate exercises, Science fair, scavenger hunts.

\section{CONCLUSIONS}

The future of AR in the bilingual and ESL classroom looks bright. This pilot provided valuable content where it can be concluded that it's very important that educator preparation programs continue training future educators with the latest technologies available and explore new ways to adapt them to the learner's generation. In the case of the bilingual and ESL classroom, this study has shown that pre-service teachers consider AR as a powerful scaffold that will enhance student engagement, motivation, and will lower the affective filter of the emerging bilinguals. This will benefit tremendously the teaching and learning process 
of K-12 students. However, more research is needed in this field, specifically in the areas of accessibility, equity and inclusion. As it was mentioned by the participants of the study, not every school district or school has the economic means for this type of technology. Beyond that many schools and schools districts have policies prohibiting the use of personal mobile tools that could offset costs. Further, many emerging bilinguals come from underrepresented and low income households that cannot afford such tools adding to the digital divide.

More research is needed to examine the future of AR and AR applications, along with its efficiency and effectiveness, in the K-12 classrooms with emerging bilinguals and ESL learners. This study mentioned the potential of integrating AR and Culturally Relevant Teaching. Combining AR with this educational implication, is something that bilingual and ESL education pre-service and in-service teachers should continue to explore, because cultures and technology play an integral part in the development of second language acquisition (Ybarra, \& Green, 2003). Finally, this study exposed the necessity of training and workshops to support teacher skill development and to ensure that all instructors are future ready and able to build effective learning environments with AR.

\section{REFERENCES}

Anderson, M., \& Bambury, S. (2018). The Periodic Table of iOS Apps for $A R$ and VR. https://ictevangelist.com/the-periodic-tableof-ios-apps-for-ar-and-vr/

Anderson, M., \&Bambury, S. (2019). The New Periodic Table of iOS Apps for AR and VR. https://ictevangelist.com/the-new-periodic-table-of-ios-apps-for-ar-and-vr-2019/

Bonner, E., \&Reinders, H. (2018). Augmented and Virtual Reality in the Language Classroom: Practical Ideas. Teaching English with Technology, 18(3), 33-53.

Chun Tie,Y., Birks,M., \& Francis, K. (2019) Grounded Theory Research: A design framework for novice researchers. Journal of Indexing Metrics https://doi.org/10.1177/2050312118822927

Dahlstrom, E., \& Bichsel, J. (2014). ECAR Study of Undergraduate Students and Information Technology, Research report. Louisville, co. http://www.educause.edu/ecar.

De la Horra Villacé, I. (2017). Realidad aumentada, una revolución educativa. EDMETIC, 6(1), 9-22. https://doi.org/10.21071/edmetic.v6i1.5762

Donally, J. (2018). Learning Transported: Augmented, Virtual and Mixed Reality for All Classrooms. International Society of Technology in Education.
Figueroa-Flores, J.F. (2015). Using Gamification to Enhance Second Language Learning. Digital Education Review, 21,32-54. https://doi.org/10.1344/der.2015.27.32-54

Figueroa-Flores, J.F. (2016). Gamification and Game-Based Learning: Two Strategies for the 21st Century Learner. World Journal of Educational Research, 3(2),507-522. http://dx.doi. org/10.22158/wjer.v3n2p507

Folkestad, J., \& O’Shea, P. (2011). An Analysis of Engagement in a Combination Indoor/Outdoor Augmented Reality Educational Game. Journal on School Educational Technology, 7(1), $30-37$.

García, O., \& Kleifgen, J. (2018). Educating Emergent Bilinguals: Policies, programs and practices for English Learners (2nded.). Teachers College Press

Gay, G. (2013). Teaching to and through cultural diversity. Curriculum Inquiry, 43, 48-70. https://doi.10.1111/curi.12002

George, C. E. (2020). Percepción de estudiantes de bachillerato sobre el uso de Metaverse en experiencias de aprendizaje de realidad aumentada en matemáticas. Pixel-Bit. Revista de Medios y Educación, (58), 143-159. https://doi.org/10.12795/ pixelbit.74367 
Glasser, B.G, \& Strauss, A.L. (1967).The Discovery of Grounded Theory: Strategies for Qualitative Research. Sociology Press.

Godwin-Jones, R. (2016). Augmented reality and language learning: From annotated vocabulary to place-based mobile games. Language Learning \& Technology 20(3), 9-19.

Kang, Y., \& Yang, K. (2020). Employing Digital Reality Technologies in Art Exhibitions and Museums: A Global Survey of Best Practices and Implications. In G. Guazzaroni \& A. S. Pillai (Eds), Virtual and Augmented Reality in Education, Art, and Museums (pp. 139-162). IGI Global. http://doi:10.4018/978-17998-1796-3

Kerawalla, L., Luckin, R., Seljeflot, S., \& Woolard, A. (2006). Making it real: Exploring the potential of augmented reality for teaching primary school science. Virtual Reality, 10(3-4), 163174. Springer-Verlag London Ltd.

Khan, T., Johnston, K., \& Ophoff, J. (2019). The Impact of Augmented Reality Application on Learning Motivation of Students. Advances in Human-Computer Interaction. 2019(7208494), 1-14. https://doi. $\operatorname{org} / 10.1155 / 2019 / 7208494$

Krashen, S. D. (1982). The Affective Filter Hypothesis. Principles and Practice in Second Language Acquisition. Pergamon Press Inc. Krippendorff, K. (2004). Content Analysis: An Introduction to Its Methodology (2nd ed.). Sage

Lee, K. (2012). Augmented Reality in Education and Training. Tech Trends, 56(2), 13-21. https://doi.org/10.1007/s11528-012-0559-3

Marín-Díaz, V. (2017) The Relationship Between Augmented Reality and Inclusive Education in Higher Education. ICT and Inclusive Education. Bordón, 69(3), 125-142. https://doi. org/10.13042/Bordon.2017.51123

Marín Díaz, V., Ramírez Hernández, M., \& Maldonado Berea, G. A. (2015). Valoraciones del profesorado universitario sobre la integración de las TIC en el aula. EDMETIC, 5(1), 177-200. https://doi.org/10.21071/edmetic.v5i1.4022

McFarland, J., Hussar, B., de Brey, C., Snyder, T., Wang, X., Wilkinson-Flicker, S., Gebrekristos, S., Zhang, J., Rathbun, A., Barmer, A., Bullock Mann, F., \& Hinz,S. (2017). The Condition of Education 2017 (NCES 2017-144). National Center for Education Statistics. https://nces.ed.gov/pubsearch/pubsinfo. asp?pubid $=2017144$

Petrucco C., \& Agostini D. (2016), Teaching our Cultural Heritage using Mobile Augmented Reality. Journal of e-Learning and Knowledge Society, 12(3), 115-128.

Saidin, N.F., Abd Halim, N.D., \& Yahaya, N. (2015). A Review of Research on Augmented Reality in Education: Advantages and Applications. International Education Studies, 8(13), 1-8. http://dx.doi.org/10.5539/ies.v8n13p1

Ybarra, R., \& Green T. (2003). Using technology to help ESL/EFL students develop language skills. The Internet TESL Journal, 9(3). http://iteslj.org/Articles/Ybarra-Technology 